\title{
ECONOMIC COSTS OF YOUTH UNEMPLOYMENT IN THE EUROPEAN UNION
}

\author{
Liva Grinevica ${ }^{1}$, Dr.oec.; Baiba Rivza ${ }^{2}$, Dr.habil.oec. \\ ${ }^{1}$ Latvian Academy of Sciences; ${ }^{2}$ Latvia University of Life Sciences and Technologies
}

\begin{abstract}
Unemployment is considered a broad macroeconomic problem that is associated with job absorption, the wasting of human resources, the performance of the labour market, the success of economic policy and even with the risk of inflationary pressures. Unemployment itself has hidden potential and has become a significant and serious social problem of the society (Novak, Darmo, 2015).

Young people have been among those most affected by the recent financial crisis. National labour force surveys (Hoffman, 2011) show that since 2008 the youth unemployment rate has risen in all the EU Member States (Hjuza \& Borbejs-Pece, 2012). The current economic instability in the context of youth's prospects and opportunities in the labour market is uncertain (Balan, 2014). Youth unemployment has also a negative effect on economic growth and productivity.

The aim of the paper is to identify the importance of youth unemployment and draw the society's attention to the consequences. In the paper, the authors provide a better understanding of losses for the country due to unemployed young people by analysing the cost of youth unemployment in the European Union using the gross domestic product (GDP) approach.
\end{abstract}

Key words: youth unemployment, costs of youth unemployment, gross domestic product (GDP). JEL code: J20, J21

\section{Introduction}

The European Union (EU) is facing a new challenge related to the so-called "lost generation" and solving the status of this generation in the global aspect. The role of youth is undeniable, and countries have to revise political positions related to the young generation, because the discontent of youth can become a major force for changing political regimes. If there are no attempts to solve the problem of youth unemployment, we might in future expect economic and political instability in the EU, as well as globally (Martincova, 2005).

The purpose of the paper was not to solve all problems associated with youth unemployment. In this case, the authors would like to introduce readers to the youth unemployment problem in the $\mathrm{EU}$, economic costs of youth unemployment and the calculation of economic losses from unemployed youth in the European Economic Area.

The main aim of the research is to calculate the lost GDP from youth unemployment in the EU.

The following tasks are set to achieve the aim:

1) to describe the main trends in youth unemployment in the EU;

2) to evaluate the theoretical findings on youth unemployment and economic costs of unemployment by different authors;

3) to calculate the lost GDP from youth unemployment in the EU in 2016.

Novelty of the research: the lost GDP due to youth unemployment in the EU in 2016 was calculated.

Research methodology: the monographic and descriptive method, statistical research methods, the graphic method, synthesis and analysis, the logical construction method, calculations of the lost GDP from youth unemployment in the EU in 2016.

Theoretical framework of the research: the research is based on other scientific research studies and findings in the economic field, statistical information provided by Eurostat. 


\section{Research results and discussion 1. Importance of youth unemployment}

The current global economic situation represents particularly difficult labour market experience for young people. Young people are disadvantaged in finding a job, especially those with low skills, without education and labour market experience. Those young people meet with discrimination when they want to enter the labour market. Youth unemployment has become a major policy challenge for governments as well as employers. Youth unemployment promotes serious consequences not only for the young unemployed but also for the state.

Authors Dao and Loungani also accent that unemployment leads to significant losses both for the unemployed and for society as a whole, the damage increases with the length of unemployment (Dao, Loungani, 2010).

According to authors Clark and Summers (1982), Bell and Blanchflower (2010) and Barbagelata (2012), the transition from school to work of young people is affected by certain factors in the labour market.

Main causes of youth unemployment:

- Social conditions of family (young parents, one parent etc.);

- Social competencies of young people (low personal and professional growth);

- The level of education (low-skilled, not educated);

- Cultural differences (national or ethnic minorities);

- Health problems (chronic or mental health problems, disability);

- Social, economic and political conditions, created by the state and society;

- Geographical conditions and economic stability (young people in rural areas, availability of transport etc.).

According to previous mentioned causes, the youth unemployment is closely linked to successful participation in society, as well as integration into the labour market.

Author Barbagelata considers that adequate level of education and training promote access to better positions on the part of young people under normal economic conditions, doubts are cast on the effectiveness of training programmes in times of crisis (Barbagelata, 2012).

Being unemployed at a young age might have a negative impact in the form of "scarring effect". Young people might be trapped in lower limits of the labour market with lower qualification opportunities, a lower wage level and with poor prospects for better jobs. This fact might in future lead to long-term unwillingness to find a job, even to a risk of social exclusion by the society (Novak, Darmo, 2015).

Blanchflower and Freeman have found that despite a deteriorating situation in labour market for young people, only few riots have occurred (Blanchflower, Freeman, 2000). Especially, youth unemployment affects social exclusion, and in the case of long-term inability by young people to find a job, it has negative consequences for future working lives in terms of lower incomes or wages (Fares, Tiongson, 2007).

Costs of unemployment include loss of income, loss of skills and qualifications, negative impacts on health, etc. For society, it is the fall in tax revenue, and increases of fiscal cost are due to unemployment benefits, income inequality and poverty increase, weakening of social cohesion (e.g. less trust in the state power) and the loss of human capital. Structural unemployment causes a mismatch between labour supply and demand (e.g. skills and geographical mobility). One of the 
reasons is the on-going price and wage rigidities. Unemployment creates significant losses to person and to the whole community (Augsts bezdarbs Latvija...., 2010).

Another metric that has a direct implication for the costs of unemployment is the duration of unemployment spells. A longer unemployment spell carries the risk of entrenching cyclical unemployment into a structural phenomenon as workers lose human capital and become detached from the labour force (Blanchard and Summers, 1986).

Overall, the economic and social costs of unemployment include:

- loss of human capital;

- social problems;

- loss of income for the unemployed;

- less tax revenues and higher government borrowing;

- inefficient use of resources;

- costs to government (lost tax revenue, lost GDP) (Economic costs of..., s.a.).

\section{Current situation in the European Union}

In the European Union and the euro area, unemployment has risen since 2008, which is due to the economic crisis which caused bankruptcy and financial trouble for many employers, and thus led to considerable job loss, less job offerings, and consequently, to a rise of the unemployment rate. Older workers are struggling to find new jobs despite their experience and knowledge, as well as young people are trying to find a job after graduating their studies (Statista, 2018).

According to Eurostat, in December 2017, 3.654 million young persons (under 25) were unemployed in the EU-28, of whom 2.574 million were in the euro area. Compared with December 2016, youth unemployment decreased by 411000 in the EU-28 and by 301000 in the euro area. In December 2017, the youth unemployment rate was $16.1 \%$ in the EU-28 and $17.9 \%$ in the euro area, compared with $18.0 \%$ and $20.3 \%$, respectively, in December 2016 (Eurostat, 2018).

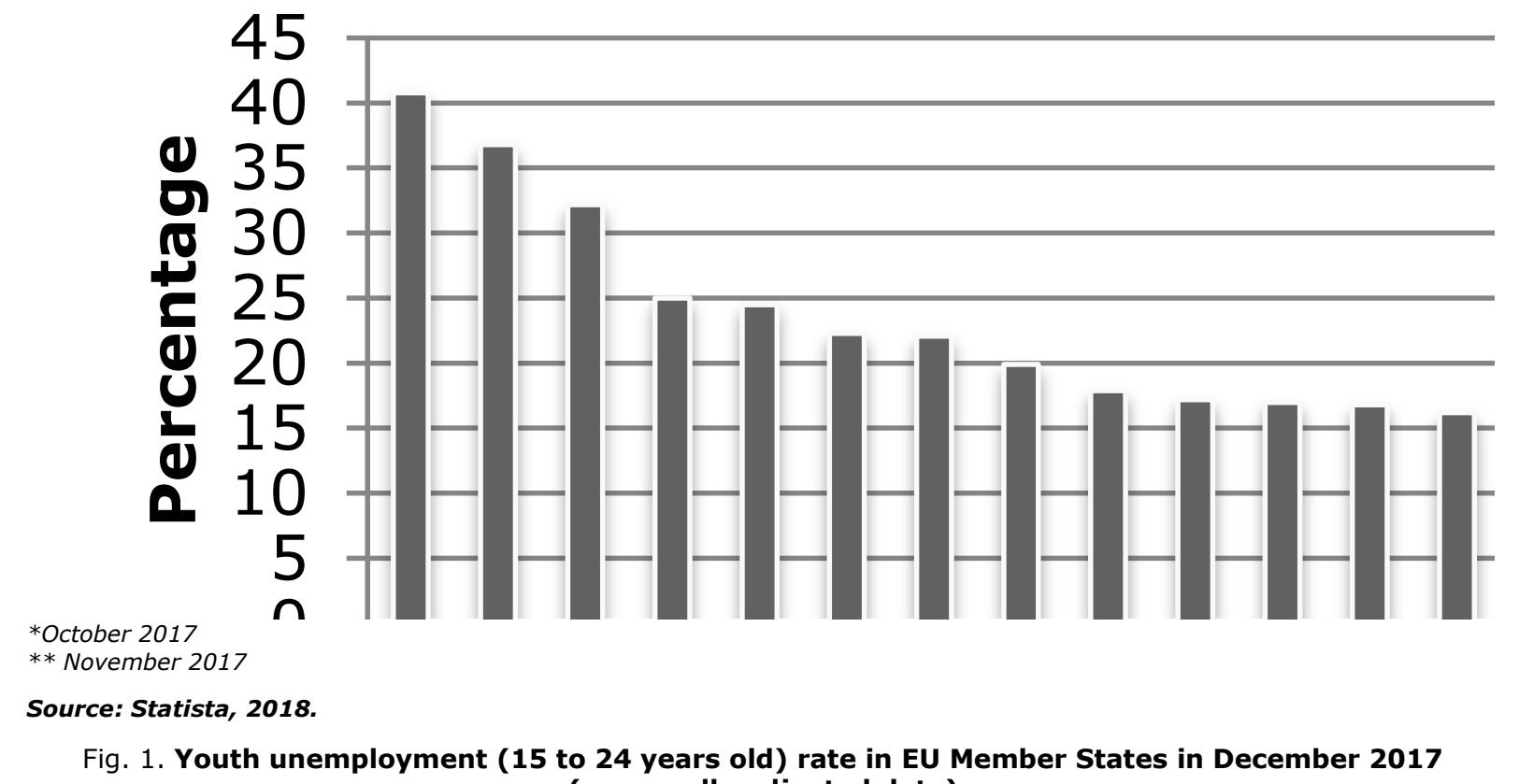

Fig. 1. Youth unemployment (15 to 24 years old) rate in EU Member States in December 2017 (seasonally adjusted data)

According to Figure 1, the statistic shows the seasonally adjusted youth unemployment (15 to 24 years old) rate in EU Member States in December 2017. In October 2017, higher youth 
unemployment rates were in Greece - $40.8 \%$, Spain - 36.8 \% and Italy - 32.2 \%, at the same time the EU average youth unemployment was only $16.1 \%$. In December 2017, the lowest rates were observed in the Czech Republic - $4.9 \%$, Germany - $6.6 \%$ and Estonia - $6.8 \%$.

An analysis of youth unemployment rates in the Baltic States shows that a lower youth unemployment rate was in Estonia - 6.8 \% (in November 2017), while in Latvia and Lithuania the youth unemployment rate was a little higher - $14.2 \%$ in Latvia and $13.1 \%$ in Lithuania. In the Baltic States, the youth unemployment rates were lower that the EU-28 average (Figure 1).

The authors consider that in Latvia the youth unemployment problem is also relevant because of the demographic situation - the proportion of young people in the total population is not high.

In foreign research studies, Latvia is positioned as a "depressive" region in the year 2030, which will have an insufficient population of young people. Thus, Latvia as a country with a businessfriendly environment will not be able to be competitive relative to other European countries and the flow of investment will be at risk, as well as passed on other, more competitive and better developed regions in demographic terms (Grinevica et al., 2016).

\section{Calculation of economic youth unemployment losses}

Losses for the state from unemployed young people can be approximated by calculating the unmanufactured volume of gross domestic product (GDP) (in the given year), taking into account the proportion of the unemployed youth in the total number of employees.

GDP is the total volume of final products and services produced in a territory during the year. It is calculated using data of domestic production (at current and constant prices), expenditure (current and constant prices) and income (only current prices) (Iekszemes kopprodukts Latvija..., 2015).

Economic costs arise because economic resources are not fully exploited due to unemployment. The consequences are a decrease in the production of goods and services, personal income and state budget revenues. However, the expenditure of the state budget is growing. Economic growth is faster if employment grows and unemployment falls. However, in order to ensure a decrease in the unemployment rate, the situation has to be consistent with any other relevant relationship, e.g. the economic growth rate must be greater than the growth rate of annual potential GDP (Bikse, 2015).

Data on gross domestic product (GDP), active population, unemployment and youth unemployment were used to calculate the economic costs of youth unemployment in the Baltic States. It was assumed that the natural employment rate is $5 \%$.

The lost GDP due to youth unemployment in the European Union member States in 2016 was calculated using data from Eurostat (Table 1).

As it is seen in Table 1, the countries with the lowest number of employed persons were Malta 189 thousand people, Luxembourg - 259 thousand and Cyprus - 354 thousand people.

For example, in 2016 the greatest lost GDP due to youth unemployment was in France EUR 54955.11 million, Italy - EUR 42607.24 million, the United Kingdom - EUR 43123.56 million and Germany - EUR 21956.21 million. 
Calculated data on the lost GDP due to youth unemployment in the European Economic Area in 2016

\begin{tabular}{|c|c|c|c|c|c|}
\hline Country & $\begin{array}{l}\text { GDP, } \\
\text { current } \\
\text { prices, milli } \\
\text { on EUR }\end{array}$ & $\begin{array}{c}\text { Active } \\
\text { population } \\
\text { (from } 15 \text { to } 24 \\
\text { years), thousan } \\
\text { d }\end{array}$ & $\begin{array}{l}\text { Employment, } t \\
\text { housand }\end{array}$ & $\begin{array}{c}\text { Youth } \\
\text { unemployment } \\
\text { (from } 15 \text { to } 24 \\
\text { years), thousand }\end{array}$ & $\begin{array}{l}\text { Lost GDP due to } \\
\text { youth } \\
\text { unemploy- } \\
\text { ment, million } \\
\text { EUR }\end{array}$ \\
\hline Belgium & 423048.4 & 372 & 4539 & 74.9 & 6631.86 \\
\hline Bulgaria & 48128.6 & 161 & 2953 & 27.7 & 428.89 \\
\hline $\begin{array}{l}\text { Czech } \\
\text { Republic }\end{array}$ & 176564.3 & 330 & 5014 & 34.6 & 1157.49 \\
\hline Denmark & 277489.1 & 482 & 2747 & 57.8 & 5546.75 \\
\hline Germany & 3144050.0 & 4186 & 40158 & 295.2 & 21956.21 \\
\hline Estonia & 21098.3 & 57 & 611 & 7.6 & 249.31 \\
\hline Ireland & 275567.1 & 292 & 2066 & 34.7 & 4396.94 \\
\hline Greece & 174199.3 & 262 & 3601 & 123.7 & 5684.82 \\
\hline Spain & 1118522.0 & 1476 & 18176 & 656.1 & 38356.58 \\
\hline France & 2228857.0 & 2766 & 26235 & 680.9 & 54955.11 \\
\hline Croatia & 46382.1 & 176 & 1561 & 55.2 & 1558.15 \\
\hline Italy & 1680522.8 & 1571 & 22231 & 593.3 & 42607.24 \\
\hline Cyprus & 18122.5 & 35 & 354 & 10.3 & 500.93 \\
\hline Latvia & 24926.7 & 75 & 862 & 13.0 & 357.13 \\
\hline Lithuania & 38668.3 & 123 & 1317 & 17.8 & 496.49 \\
\hline Luxembourg & 53004.8 & 21 & 259 & 3.9 & 758.23 \\
\hline Hungary & 113730.8 & 346 & 4308 & 44.7 & 1121.07 \\
\hline Malta & 9926.6 & 27 & 189 & 3.0 & 149.69 \\
\hline Netherlands & 702641.0 & 1408 & 8216 & 152.3 & 12373.61 \\
\hline Austria & 353296.9 & 565 & 4142 & 63.5 & 5145.49 \\
\hline Poland & 425980.2 & 1381 & 15898 & 243.8 & 6205.89 \\
\hline Portugal & 185179.5 & 364 & 4369 & 101.8 & 4099.04 \\
\hline Romania & 169771.5 & 607 & 8166 & 125.1 & 2470.79 \\
\hline Slovenia & 40418.1 & 68 & 902 & 10.3 & 438.46 \\
\hline Slovakia & 81154.0 & 206 & 2471 & 45.8 & 1428.98 \\
\hline Finland & 215615.0 & 323 & 2378 & 65.1 & 5607.53 \\
\hline Sweden & 465186.2 & 642 & 4734 & 121.6 & 11351.57 \\
\hline $\begin{array}{l}\text { United } \\
\text { Kingdom }\end{array}$ & 2395810.0 & 4434 & 30406 & 576.1 & 43123.56 \\
\hline
\end{tabular}

Source: authors' construction based on Eurostat data

As shown in Table 1, in 2016 the lowest lost GDP due to youth unemployment was in Malta EUR 149.69 million, Estonia - EUR 249.31 million, Latvia - EUR 357.13 million and Bulgaria EUR 428.89 million.

\section{Conclusions}

According to the research results, the youth unemployment is a serious microeconomic and macroeconomic problem. Youth unemployment affects not only a young people social exclusion from society but also increases economic costs and decreases revenues for the state.

Compared with other unemployed groups, young people are less likely to become long-term unemployed.

The main reasons for youth unemployment are the lack of education as well as qualitative work experience in the corresponding profession. 
Youth unemployment rates (from 15 to 24 year olds) vary widely across European countries. In December 2017, Greece (40.8\% in October 2017), Spain (36.8\%) and Italy (32.2\%) had the highest youth unemployment rates, but such countries as the Czech Republic (4.9\%), Germany (6.6 \%) and Estonia (6.8 \% in November 2017) had the lowest rates.

Latvia still has the highest unemployment rate among the Baltic States. In December 2017, in Latvia the youth unemployment (from 15 to 24 year olds) rate was $14.2 \%$, Lithuania $-13.1 \%$ and Estonia only 6.8 \% (in November 2017).

According to the research results, in 2016 the greatest lost GDP due to youth unemployment was in France - EUR 54955.11 million, Italy - EUR 42607.24 million and the United Kingdom EUR 43123.56 million, however, the lowest lost GDP due to youth unemployment was in Malta EUR 149.69 million, Estonia - EUR 249.31 million and Latvia - EUR 357.13 million.

\section{Acknowledgements}

The preparation of the paper was supported by National Research Program 5.2. Economic Transformation, Smart Growth, Governance and Legal Framework for the State and Society for Sustainable Development - a New Approach to the Creation of a Sustainable Learning Community, the project EKOSOC-LV.

\section{Bibliography}

1. Augsts bezdarbs Latvija - nolemtiba vai izvele? (High Unemployment in Latvia - a Fiction or Choice?) (2010) JSC Swedbank. Retrieved: https://www.swedbank.Iv/files/analitiskie_materiali/swedbank_petijums/Swedbank_Petijums_2010_12_LV. pdf. Access: 02.02.2018.

2. Balan, M. (2014) Analysis of Unemployment among Young Individuals from Romania by Econometric Methods. International Auditing \& Risk Management, No. 3 (35), pp. 90-97.

3. Barbagelata, H.H. (2012) Youth, Unemployment and Education. Cambridge Scholars Publishing. pp. 3-12.

4. Bell, D. N. F., Blanchflower, D. G. 2010. Youth Unemployment: Deja Vu? Institute for the Study of Labour, IZA Discussion Paper No. 4705, Germany, Bonn, pp. 1- 58.

5. Bikse, V. (2015). Makroekonomika: teorija un politika (Macroeconomics: Theory and Policy). Liepaja: Liepaja University, published by "LiepU LiePA tipografija", pp. 69-91.

6. Blanchflower, D. G., Freeman, R. B. (2000). The Declining Economic Status of Young Workers in OECD Countries, Youth Employment and Joblessness in Advanced Countries. NBER. pp. 19-56.

7. Clark, K. B., Summers, L. H. (1982). The Dynamics of Youth Unemployment, NBER Chapter 2, p. 72.

8. Dao M., Loungani P. (2010) The Human Cost of Recessions: Assessing it, Reducing it. IMF Staff Position note SPN/10/17.

9. Economic Costs of Unemployment (s.a.). Retrieved: https://www.economicshelp. org/macroeconomics/unemployment/costs/. Access: 06.02.2018.

10. Employment and Activity by Sex and Age - Annual Data. Retrieved: http://appsso.eurostat.ec.europa.eu/nui/show.do?dataset=Ifsi_emp_a\&lang=en. Access: 02.02.2018.

11. Fares, J., Tiongson, E. R. (2007). Youth Unemployment, Labour Market Transitions, and Scarring: Evidence from Bosnia and Herzegovina. In: Policy, Research, Working paper. No. WPS 4183, Vol. 1.

12. GDP and main components (output, expenditure and income). Retrieved: http://appsso.eurostat.ec.europa.eu/nui/show.do?dataset=nama_10_gdp\&lang=en. Access: 02.02.2018.

13. Grinevica, L., Rivza, B., Rivza, P. (2016) Scenarios for Reducing Youth Unemployment and Promoting Sustainability in the Regions of Latvia. In: Journal of Security and Sustainability Issues, Vol.5., No. 3., ISSN 2029-7017 print/ ISSN 2029-7025 online, pp. 437-449.

14. Hjuza, D., Borbejs- Pece, T. B., (2012) Jauniesu bezdarbs: muslaiku krize. Muzilga karjeras atbalsta ricibpolitikas nozime darba piedavajuma un pieprasijuma joma (Youth Unemployment: the Current Crisis. A Lifelong Career Policy in the Field of Job Supply and Demand). European Lifelong Career Support Policy Network. pp. 1-20.

15. Hoffman, N. (2011). Schooling in the Workplace- How Six of the World's Best Vocational Education Systems Prepare Young People for Jobs and Life. Harvard Education Press, Cambridge, MA.

16. Iekszemes kopprodukts Latvija (Gross Domestic Product in Latvia) (2015). Retrieved: http://www.csb.gov.Iv/statistikas-temas/metodologija/iekszemes-kopprodukts-latvija-kopa-eks-9534403.html. Access: 28.01.2018. 
17. Martincova, M. (2012) Openness of Economy and Economic Growth. Globalization and Higher Education in Economics and Business Administration. Proceedings of the $6^{\text {th }}$ International Conference. Alexandru Ioan Cuza University Press, pp. 588-592.

18. Novak, M., Darmo, L. (2015). The Youth Unemployment in the European Area. Proceedings of the SGEM International Multidisciplinary Scientific Conference on Social Sciences and Arts. Section economics and Tourism. pp. 963-970.

19. Unemployment by sex and age - annual average http://appsso.eurostat.ec.europa.eu/nui/submitViewTableAction.do\# . Access: 02.02.2018.

20. Unemployment statistics (2018). Retrieved: http://ec.europa.eu/eurostat/statisticsexplained/index.php/Unemployment_statistics. Access: 07.02.2018.

21. Youth Unemployment Rate in EU Member States as of December 2017 (seasonally adjusted) (2018) Statista. Retrieved: https://www.statista.com/statistics/266228/youth-unemployment-rate-in-eu-countries/. Access: 06.02.2018. 